\title{
Subjetividades, resistencias y tránsitos en la comunicación
}

La idea de los medios de comunicación -industriales o independientes- como espacios de disputa, construcción y confrontación de subjetividades no es difícil de imaginar. Lo difícil es definir entradas para estudiar algo tan etéreo, tan difícil de asir como lo subjetivo. Dentro del Grupo de Investigación Comunicación y Subjetividades, estamos en constante búsqueda de conceptos y teorías que nos permitan continuar revisando las interacciones, los espacios de negociación o las mediaciones existentes entre la producción cultural, los sucesos comunicacionales y sociales -en general, la producción de narrativas y discursos- y las personas. «Lo personal es político», se escucha hoy más que nunca, desde las trincheras de la experiencia cotidiana, desde el activismo feminista o el ambiental, desde la protesta social, desde el arte. Lo personal es colectivo.

En el proceso de preparación de este número surge la necesidad de dialogar, desde este espacio académico, con lo que está sucediendo hoy en toda Latinoamérica. ¿Cómo complementar la mirada que ya estaba materializándose en esta publicación?

En lugar de construir una introducción tradicional para el contenido de esta revista, nos propusimos conversar con voces que pudieran ayudarnos a relacionar la discusión sobre subjetividades con el contexto político y social actual, un diálogo que potencie y articule la lectura de los seis textos que contiene esta publicación. Desde Chile, Sergio Villalobos-Ruminott, profesor de la Universidad de Michigan que investiga sobre prácticas visuales y culturales en Latinoamérica desde una perspectiva filosófica, estética y psicoanalítica; y, desde Bolivia, Gabriela Zamorano, antropóloga visual mexicana que vive entre esos dos países trabajando y estudiando comparativamente sobre archivos fotográficos, y prácticas visuales y audiovisuales, nos dan herramientas y perspectivas claves que enriquecen la lectura y nos invitan a pensar en nuestro rol como ciudadanos latinoamericanos, pero también como peruanos 
aparentemente ajenos a lo que sucede en nuestro entorno. Cada uno a su estilo y desde su propia subjetividad, aprovechan cada pregunta para mostrarnos un espejo en el cual mirarnos.

Esas dos conversaciones enmarcan el contenido de esta edición, dividido de forma lúdica en tres secciones: Cuerpo y materia, Ideología y tránsitos, y Resistencias. En la primera, Talía Dajes y Sophia Gómez proponen miradas sobre las estéticas de la descomposición y la violencia, respectivamente, en el cine. El cuerpo atravesado por lo social y lo subjetivo, lo humano y lo no humano conviviendo en los universos de la ficción y de la no ficción. En la segunda, Bruno Rivas y Alexis Patiño-Patroni desentrañan el sistema neoliberal con dos lecturas que se complementan: el activismo político, por un lado, y la subversión simbólica, por el otro. Y, en la tercera, Lorena Pastor, y Raisa Ferrer y Fabiola Bustamante nos cuentan sobre resistencias ante lo hegemónico.

Hay dos ideas finales que nos interesa remarcar desde esta publicación. Nuestros discursos - orales, escritos, gestuales, visuales, audiovisuales, sonoros- nos revelan. Hablan desde la subjetividad, la ideología, el lugar que se ocupa en el mundo y desde el cual se mira. Así, desde el terreno de la representación, es posible entender el hoy, contextualizarlo dentro de una tradición o repertorio de producción de símbolos y relacionarlo con la historia, pero también es posible «leer» el futuro. Las construcciones subjetivas se ponen en juego y son también espacios de proyección de deseos, de invención y fantasía. Tal como comenta Gabriela Zamorano en su entrevista, las ficciones sobre uno mismo permiten «experimentar escenarios políticos futuros».

Hace falta pensarnos desde el Sur. Puesto que desde acá producimos, es necesario construir una tradición epistemológica y política liberadora, que incluya una reflexión sobre y desde el espacio que habitamos y las formas en que lo habitamos, que cuestione las tradicionales maneras en que nos hemos mirado y las categorías en las que estamos inscritos -incluso la propia categoría «sur»-, y desde ahí empezar a construir campos de significado y estudio para lo subjetivo. No es fácil despojarnos de marcas y adoctrinamientos, de la presencia del inglés para fines académicos o del colonialismo del saber. Pero, a continuación, con todas las contradicciones que ello implica, presentamos algunos intentos. 
Un agradecimiento especial a los miembros del Grupo de Investigación Comunicación y Subjetividades por las sugerencias, críticas y discusiones aportadas para la elaboración de este número.

Sofía Velázquez Núñez y Nohelia Pasapera Tupiño 